\title{
GAYA KEPEMIMPINAN KEPALA BIRO INVENTORY PADA PT SEMEN TONASA KABUPATEN PANGKAJENE KEPULAUAN
}

\author{
Harbani P', Syahriah Sari ${ }^{2}$, Muh. Riswandi Alwi ${ }^{3}$ \\ ${ }^{1,2}$ Dosen Jurusan Admiistrasi Niaga, Politeknik Negeri Ujung Pandang \\ ${ }^{3}$ Mahasiswa Jurusan Admiistrasi Niaga, Politeknik Negeri Ujung Pandang
}

syahriahsari@poliupg.ac.id

\begin{abstract}
ABSTRAK
Kepemimpinan dalam suatu organisasi merupakan hal yang sangat fundamental dalam tujuan pencapaian organisasi. Sukses tidaknya seorang pemimpin dalam melaksanakan kepemimpinannya ditentukan oleh tingkat keterampilan teknis yang dimilikinya, dan keahliannya dalam menggerakkan orang lain untuk bekerja dengan baik. Sehubungan dengan pentingnya pemilihan gaya kepemimipinan, Kepala Biro Inventory pada PT Semen Tonasa Kabupaten Pangkajene Kepulauan Periode 2019 terlihat memiliki perilaku kepemimpinan yang masih belum maksimal dalam hal berorientasi kepada karyawan. Mengenai penentuan keputusan kebijakan, Kepala Biro terlihat kurang melibatkan karyawan. Selanjutnya, pimpinan nampak belum menunjukkan perannya dalam mnghadapi situasi dan kondisi serta perilaku para karyawannya.

Penelitian ini bertujuan untuk mengatahui gaya kepemimpinan Kepala Biro Inventory pada PT Semen Tonasa Kabupaten Pangkajene Kepulauan Periode 2019. Penelitian ini menggunakan tipe penelitian deskriptif. Teknik penarikan sampel yang digunakan ialah teknik sampling jenuh, sedangkan metode pengumpulan data yang digunakan yaitu wawancara dan kuesioner. Data yang diperoleh menggunakan analisis kuantitatif, dan disajian dalam bentuk tabel distribusi frekuensi, dimana skala yang digunakan adalah skala likert.

Hasil penelitian ini menggambarkan bahwa gaya kepemimpinn yang lebih dominan diterapkan oleh Kepala Biro Inventory PT Semen Tonasa Kabupaten Pangkajene Kepulauan Periode 2019 adalah gaya kepemimpinan otokratik.
\end{abstract}

Kata kunci: Kepemimpinan, Gaya Kepemimpinan

\section{ABSTRACT}

Leadership in an organization is very in achieving organizational goals. The success or faikure of aleader in managing his leadership is determined by the level of skill he has, and his axpertise to make the others to work well. In connectoin with the leadership style, the inventory of the Bureau Chief at PT Semen Tonasa, Pangkajene Islands, in the 2019 period seems to have leadership competence that has not been maximized in matters realting to employees. Regarding policy decisions, the Bureau Chief is seen as not involving employees. Furthermore, leadership seems to have not demonstrated its role in the discussions and conditions of the employees.

This research purpose is to learn about leadership stle of the head of the inventory Bureau at PT Semen Tonasa, Pangkajene Kepualauan Regency in th 2019 period. This research uses descriptive researc type. The sampling technique used, observation, interviews, and questionnaires. Data obtained using quantitative data analysis, and presented in the form og frequency distribution tables, where the scale used is the Likert scale.

The results of this research reveal that the most dominant leadership style applied by the Head of the Inventory Bureau of PT Semen Tonasa, Pangkajene Kepulauan Regency in the 2019 period was the autocratic leadership style.

Keywords: Leadership, Leadership Style 


\section{PENDAHULUAN}

Berdirinya suatu organisasi tentunya didasarkan oleh suatu tujuan yang ingin dicapai. Suatu organisasi baik organisasi formal maupun non-formal tentunya mempunyai visi dan misi yang menjadi landasan untuk menggerakkan suatu organisasi dalam mencapai tujuannya. Hari Lubis dalam Nawawi (2016) mengatakan "Organisasi adalah suatu kesatuan sosial dari sekelompok manusia yang saling berinteraksi menurut pola tertentu, sehingga setiap anggotanya memiliki fungsi dan tugas masing-masing, yang sebagai satu kesatuan mempunyai tujuan tertentu dan batas-batas yang jelas, sehingga dapat dipisahkan secara tegas dari lingkungannya". Sejatinya, untuk menjalankan visi dan misi yang telah ditetapkan, suatu organisasi tentu membutuhkan seorang pemimpin. Kartono dalam Pasolong (2019) mengatakan "pemimpin adalah seorang pribadi yang superioritas, sehingga ia memiliki kewibawaan dan kekuaasaan untuk menggerakkan orang lain untuk melakukan usaha guna mencapai sasaran tertentu".

Sehubungan dengan pentingnya seorang pemimpin, Davis dalam Pasolong (2015) menyatakan bahwa "tanpa kepemimpinan, suatu organisasi adalah kumpulan orang-orang dan mesin-mesin yang tidak teratur, kacau balau". Demikian pentingnya peranan pemimpin dalam suatu organisasi, sehingga dapat dikatakan bahwa yang menentukan berhasil atau tidaknya suatu organisasi ditentukan oleh seorang pemimpin. Sebaliknya, sukses tidaknya seorang pemimpin dalam melaksanakan kepemimpinannya ditentukan oleh tingkat keterampilan teknis yang dimilikinya, dan keahliannya dalam menggerakkan orang lain untuk bekerja dengan baik.

Sehubungan dengan pentingnya pemilihan gaya kepemimpinan, Pasolong (2015) mengatakan bahwa "pemilihan gaya kepemimpinan yang benar disertai dengan motivasi eksternal yang tepat dapat mengarahkan pencapaian tujuan perseorangan maupun tujuan birokrasi".

PT Semen Tonasa Kabupaten Pangkajene Kepulauan merupakan organisasi yang bergerak dalam industri semen yang memiliki beberapa bagian dalam struktur organisasinya, salah satunya ialah bagian Biro Inventory. Biro Inventory PT Semen Tonasa Kabupaten Pangkajene Kepulauan adalah bagian yang bertanggungjawab penuh dalam mengelola persediaan pada PT Semen Tonasa Kabupaten Pangkajene Kepulauan. Biro Inventory sebagai sebuah bagian dari organisasi juga memiliki pemimpin yang biasa disebut kepala Biro Inventory. Sebagai pemimpin, Kepala Biro haruslah memiliki kepemimimpinan yang tepat agar seluruh elemen pada bagian Biro Inventory dapat berjalan dan terkoordinasikan dengan baik dan teratur.

Pada era globalisasi seperti saat ini, perusahaan menuntut karyawannya agar selalu bekerja efektif dan efisien serta berinovasi untuk dapat bersaing dengan perusahaan lainnya. Begitupun pada Biro Inventory PT Semen Tonasa Kabupaten Pangkajene Kepulauan, aktivitas kerja yang sangat padat terkadang menimbulkan kesalahan komunikasi antar karyawan, sementara dalam mengatasi masalah seperti ini peran pemimpin sangatlah penting. Akan tetapi, Kepala Biro Inventory ditengarai masih belum menujukkan perannya untuk turun menyelesaikan masalah yang terjadi. Hal ini dapat berdampak buruk dikarenakan konflik yang terjadi jika dibiarkan begitu saja akan semakin membesar sehinga mempengaruhi kinerja atau produktivitas karyawan. Selanjutnya, perilaku kepemimpinan yang berorientasi pada karyawan masih belum maksimal, hal ini didasari atas banyak hal diantaranya.Dalam hal penentuan keputusan mengenai kebijakan, pimpinan terlihat tidak melibatkan karyawan, selanjutnya pimpinan nampak belum menunjukkan perannya dalam menghadapi situasi dan kondisi serta perilaku para bawahannya, sehingga suasana kerja menjadi terlihat kaku. Oleh karena itu, pemilihan Gaya Kepemimpinan yang baik dan tepat merupakan hal fundamental yang perlu diperhatikan oleh seorang Kepala Biro Inventory PT Semen Tonasa Kabupaten Pangkajene Kepulauan. 
Berdasarkan uraian di atas, penulis mengangkat judul "Gaya Kepemimpinan Kepala Biro Inventory pada PT Semen Tonasa Kabupaten Pangkajene Kepulauan”.

\section{Rumusan Masalah}

Berdasarkan latar belakang masalah yang telah diuraikan, maka ditetapkan pokok masalah ialah Gaya Kepemimpinan apayang diterapkan Kepala Biro Inventory pada PT Semen Tonasa Kabupaten Pangkajene Kepulauan Periode 2019.

\section{Tujuan Penelitian}

Sesuai dengan perumusan masalah di atas, maka tujuan penelitian ini adalah untuk mengetahui Gaya Kepemimpinan kepala Biro Inventory padaPT Semen Tonasa Kabupaten Pangkajene Kepulauan Periode 2019.

\section{TINJAUAN PUSTAKA}

\subsection{Konsep Pemimpin}

Kata pemimpin berasal dari dasar kata "pimpin" yang memiliki arti bimbing atau tuntun, sehingga kata pemimpin yang membimbing atau yang menuntun, Pasolong (2019) mengatakan konsep "pemimpin" berasal dari kata asing "leader". Selanjutnya Pasolong (2019) mengatakan bahwa "Pemimpin adalah seorang yang memiliki kecakapan tertentu yang dapat mempengaruhi para pengikutnya untuk melakukan kerjasama ke arah pencapaian tujuan yang telah ditentukan sebelumnya". Hasibuan dalam Nur (2017) mengatakan "Pemimpin adalah seseorang dengan wewenang kepemimpinannya mengarahkan bawahannya untuk mengerjakan sebagian dari pekerjaannya dalam mencapai tujuan".

Pendapat lain dikemukakan oleh Kartono (2016) bahwa "Pemimpin adalah pribadi yang memiliki kecakapan khusus, dengan atau tanpa pengangkatan resmi dapat mempengaruhi kelompok yang dipimpinnya, untuk melakukan usaha bersama mengarah pada pencapaian sasaran-sasaran tertentu".

Berdasarkan beberapa defenisi di atas, maka dapat disimpulkan bahwa yang dimaksud dengan pemimpin adalah seseorang yang memiliki kemampuan dan kapasitas untuk mengarahkan orang lain dalam melaksanakan tugas yang berhubungan dengan pencapaian tujuan.

\subsection{Pimpinan}

Setiap dan semua organisasi apapun jenisnya pasti memiliki dan memerlukan pimpinan, Pasolong (2015) mengatakan "Pimpinan adalah orang yang menduduki jabatan dalam suatu organisasi atau birokrasi". Rukmana (2007) mengemukakan "Pimpinan mencerminkan kedudukan seseorang atau kelompok orang pada hirarki tertentu dalam suatu organisasi formal maupun nonformal".

Dari beberapa definisi diatas, dapat ditarik kesimpulan bahwa pimpinan adalah jabatan atau posisi seseorang atau kelompok di dalam sebuah organisasi.

\subsection{Perbedaan Pemimpin dan Pimpinan}

Pemimpin dan pimpinan merupakan dua istilah yang hampir sama namun memppunyai arti yang berbeda. Rukmana dalam Pasolong (2015) mengatakan "Pejabat sudah pasti pimpinan, tapi belum tentu dapat berperan sebagai pemimpin". Pasolong (2015) "mengatakan bahwa "Pemimpin (leader) adalah orang yang melakukan atau menjalankan kepemimpinan (leadership). Sedangkan pimpinan adalah mencerminkan kedudukan seseorang atau sekelompok orang pada hierarki tertentu dalam birokrasi formal maupun informal".

\subsection{Kepemimpinan}

Anoraga dan suyati dalam Nawawi (2016) mengatakan bahwa "Kepemimpinan adalah kemampuan mempengaruhi aktivitas orang lain melalui komunikasi, baik individual maupun kelompok ke arah pencapaian tujuan”. Selanjutnya Greenberg dan Baron dalam Wibowo 
(2016:3) mendefenisikan "Kepemimpinan sebagai proses di mana satu individu mempengaruhi anggota kelompok lain menuju pencapaian tujuan kelompok atau organisasional yang didefinisikan". Adapun Rivai (2014) mengatakan bahwa "Kepemimpinan secara luas meliputi proses memengaruhi dalam menentukan tujuan organisasi, memotivasi perilaku bawahan dalam mencapai tujuan, memengaruhi untuk memperbaiki kelompok dan budayanya".

Dari beberapa definisi diatas, dapat disimpulkan bahwa kepemimpinan adalah proses mempengaruhi atau memberi contoh oleh pemimpin kepada pengikutnya dalam upaya mencapai tujuan oraganisasi.

\subsection{Gaya Kepemimpinan}

Pada dasarnya gaya kepemimpinan, Pasolong (2015) menagatakan bahwa "Gaya kepemimpinan adalah suatu cara yang dipergunakan oleh seorang pemimpin dalam mempengaruhi, mengarahkan, mendorong, dan mengendalikan bawahannya rangka pencapaian tujuan organisasi secara efektif dan efisien". Adapun dalam pembahasan yang sama, Nawawi (2016) mengartikan "gaya kepemimpinan sebagai perilaku atau cara yang dipilih dan dipergunakan pemimpin dalam mempengaruhi pikiran, perasaan, sikap dan perilaku para anggota organisasi/bawahannya".

Sehubungan dengan pembahasan gaya kepemimpinan, Siagian (2010) mengatakan bahwa " meskipun belum terdapat kesepakatan bulat tentang tipologi kepemimpinan yang secara luas dikenal dewasa ini, lima gaya kepemimpinan yang diakui keberadaannya ialah :

Adapun Siagian membahas kelima gaya kepemimpinan diatas adalah sebagai berikut:

\section{Gaya Otokratik}

Pemahaman tentang literatur yang membahas tipologi kepemimpinan segera menunjukkan bahwa semua ilmuwan yang berusaha mendalami berbagai segi kepemimpinan yang tergolong sebagai pemimpin yang otokratik memiliki serangkaian karakteristik yang dapat dipandang sebagai karakteristik negatif. Analisis yang rasional memang membenarkan pandangan yang demikian.

Dilihat dari segi persepsinya, seorang pemimpin yang otokratik adalah seorang yang egois. Egoismenya yang sangat besar akan mendorongnya memutarbalikkan kenyataan yang sebenarnya sehingga sesuai dengan apa yang secara subjektif diinterpretasikan sebagai kenyataan. Misalnya, dalam menginterpretasikan disiplin para bawahan dalam organisasi. Seorang pemimpin yang otokratik akan menerjemahkan disiplin kerja yang tinggi yang ditunjukkan oleh para bawahannya sebagai perwujudan kesetiaan para bawahan itu kepadanya, padahal sesungguhnya disiplin kerja itu didasarkan kepada ketakutan, bukan kesetiaan. Egonya yang sangat besar menumbuhkan dan mengembangkan persepsinya bahwa tujuan organisasi identik dengan tujuan pribadinya dan oleh karenanya organisasi diperlakukannya sebagai alat untuk mencapai tujuan pribadi tersebut.

Seorang pemimpin yang otoriter akan menunjukkan berbagai sikap yang menonjolkan "keakuan-nya" antara lain dalam bentuk:

a. Kecenderungan memperlakukan para bawahannya sama dengan alat-alat lain dalam organisasi, seperti mesin, dan dengan demikian kurang menghargai harkat dan martabat mereka,

b. Pengutamaan orientasi terhadap pelaksanaan dan penyelesaian tugas tanpa mengkaitkan pelaksanaan tugas itu dengan kepentingan dan kebutuhan para bawahan,

c. Pengabaian peranan para bawahan dalam proses pengambilan keputusan dengan cara memberitahukan kepada para bawahan tersebut bahwa ia telah mengambil keputusan tertentu dan para bawahan itu diharapkan dan bahkan dituntut untuk melaksanakannya saja.

Dengan demikian ia tidak akan mau menerima saran dan pandangan dari para bawahannya. Apalagi kritik yang akan serta merta dianggap sebagai usaha merongrong 
kekuasaan yang dimiliknya. Perilaku yang menonjolkan kekuasaan formal menjadi salah satu karakteristik dari pemimpin yang otokratik.

Dari pembahasan singkat di atas kiranya jelas bahwa dalam kehidupan organisasional yang menjunjung tinggi harkat and martabat manusia dan berbagai bentuk kebutuhan, keinginan dan harapannya - yang kesemuanya bermuara pada apa yang dewasa ini dikenal dengan istilah "peningkatan mutu hidup" seseorang sebagai pribadi yang khas dan utuh - tipe pemimpin yang otokratik bukanlah tipe yang diinginkan.

\section{Gaya Paternalistik}

Gaya paternalistik banyak terdapat di lingkungan masyarakat yang masih bersifat tradisional, umumnya di masyarakat yang agraris. Popularitas pemimpin yang paternalistik ditentukan oleh beberapa faktor, seperti:

a. Kuatnya ikatan primordial

b. Extended Family System

c. Kehidupan masyarakat yang komunalistik

d. Peranan adat istiadat yang sangat kuat dalam kehidupan bermasyarakat

e. Masih dimungkingkannya hubungan pribadi yang intim antara seorang anggota masyarakat dengan anggota masyarakat lainnya.

Persepsi seorang pemimpin yang paternalistik tentang peranannya dalam kehidupan organisasional dapat dikatakan diwarnai oleh harapan para pengikutnya kepadanya. Harapan itu pada umumnya berwujud keinginan agar pemimpin mereka mampu berperan sebagai bapak yang bersifat melindungi dan yang layak dijadikan sebagai tempat bertanya dan untuk memperoleh petunjuk.

Para bawahan biasanya mengharapkan seorang pemimpin yang paternalistik mempunyai sifat yang tidak mementingkan diri sendiri melainkan memberikan perhatian terhadap kepentingan dan kesejahteraan para bawahannya. Akan tetapi sebaliknya, pemimpin yang paternalistik mengharapkan bawha kehadiran atau keberadaannya dalam organisasi tidak lagi dipertanyakan oleh orang lain.

Konsekuensi dari perilaku demikian adalah bahwa para bawahan tidak dimanfaatkan sebagai sumber informasi, ide dan saran. Berarti para bawahan tidak didorong untuk berpikir secara inovatif dan kreatif. Penekanan yang berlebihan terhadap kebesamaan tidak memungkinkan pertumbuhan dan pengembangan individu sesuai dengan bakat dan potensi masing-masing, yang sesungguhnya sangat dibutuhkan dalam tata kehidupan organisasi modern.

\section{Gaya Kharismatik}

Seorang pemimpin yang kharismatik adalah seorang yang dikagumi oleh banyak pengikut meskipun para pengikut tersebut tidak selalu dapat menjelaskan secara konkret mengapa orang tertentu itu dikagumi.

Penampilan fisik ternyata bukan ukuran yang berlaku umum karena ada pemimpin yang dipandang sebagai pemimpin yang kharismatik yang kalau hanya dilihat dari penampilan fisiknya saja sebenarnya tidak atau kurang mempunyai daya tarik. Usia pun tidak selalu dijadikan ukuran. Sejarah telah membuktikan bahwa seorang yang berusia relatif muda pun mendapat julukan sebagai pemimpin kharismatik jumlah harta yang dimiliki pun nampaknya tidak bisa digunakan sebagai ukuran. Ada orang yang tergolong sebagai pemimpin yang kharismatik.

Sesungguhnya sangat menarik untuk memperhatikan bahwa para pengikut seorang pemimpin yang kharismatik tidak mempersoalkan nilai-nikai yang dianut, sikap dan perilaku serta gaya yang digunakan oleh pemimpin yang diikutinya itu. Bisa saja seorang pemimpin yang kharismatik menggunakan gaya yang otokratik atau diktatorial, para pengikutnya tetap setia kepadanya. Mungkin pula seorang pemimpin yang kharismatik menggunakan gaya yang 
paternalistik, tetap ia tidak kehilangan daya pikatnya. Daya tariknya pun tetap besar bila ia menggunakan gaya yang demokratik atau partisipatif.

\section{Gaya laissez Faire}

Dapat dikatakan bahwa persepsi seorang pemimpin yang laissez faire tentang peranannya sebagai seorang pemimpin berkisar pada pandangannya bahwa pada umumnya organisasi akan berjalan lancar dengan sendirinya karena para anggota organiasai terdiri dari orang-orang yang sudah dewasa yang mengetahui apa yang menjadi tujuan organisasi, sasaran-sasaran apa yang ingin dicapai, tugas apa yang harus ditunaikan oleh masing-masing anggota dan seorang pimpinan tidak perlu terlalu sering melakukan interfensi dalam kehidupan organisasional. Singkatnya, seorang pemimpin yang laissez faire melihat peranannya sebagai "polisi lalu lintas". Dengan anggapan bahwa para anggota organisasi sudah mengetahui dan cukup dewasa untuk taat kepada peraturan permainan yang berlaku, seorang pemimpin yang laissez faire cenderung memilih peranan yang pasif dan membiarkan organisasi berjalan menurut temponya sendirit tanpa banyak mencampuri bagaimana organisasi harus dijalankan dan digerakkan.

Bertitik tolak dari nilai-nilai organisasional demikian, sikap seseorang pemimpin yang laissez faire dalam memimpin organisasi dan para bawahannya biasanya adalah sikap yang permisif, dalam arti bahwa para anggota organisasi boleh saja bertindak sesuai dengan keyakinan dan bisikan hati nuraninya asal saja kepentingan bersama tetap terjaga dan tujuan organisasi tetap tercapai. Prakarsanya dalam menyusun struktur tugas para bawahan dapat dikatakan minimum. Kepentingan dan kebutuhan para bawahan itu mendapat perhatian besar karena dengan terpeliharanya kepentingan dan terpuaskannya berbagai kebutuhan para bawahan itu, mereka akan dengna sendirinya berperilaku positif dalam kehidupan organisasionalnya.

Dengan telah mencoba mengidentifikasikan karakteristik utama seorang pemimpin yang laissez faire ditinjau dari kriteria persepsi, nilai, sikapa dan perilaku di atas, mudah menduga bahwa gaya kepemimpinan yang digunakannya adalah sedemikian rupa sehingga:

a. pendelegasian wewenang terjadi secara ekstensif,

b. pengambilan keputusan diserahkan kepada para pejabat pimpinan yang lebih rendah dan kepada para petugas operasional, kecuali dalam hal-hal tertentu yang nyata-nyata menuntut keterlibatannya secara langsung,

c. status quo organisasional tidak tertanggu,

d. penumbuhan dan pengembangan kemampuan berpikir dan bertindak yang inovatif dan kreatif diserahkan kepada para anggota organisasi yang bersangkutan sendiri,

e. sepanjang dan selama para anggota organisasi menunjukkan perilaku dan prestasi kerja yang memadai, intervensi pimpinan dalam perjalanan organisasi berada pada tingkat yang minimum.

\section{Gaya Demokratik}

Baik dikalangan ilmuwan maupun dikalangan praktisi terdapat kesepakatan bahwa tipe pemimpin yang paling ideal dan paling didambakan adalah pemimpin yang demokratik. Memang umum diakui bahwa pemimpin yang demokratik tidak selalu merupakan pemimpin yang paling efektif dalam kehidupan organisasional karena ada kalanya, dalam hal bertindak dan mengambil keputusan, bisa terjadi keterlambatan sebagai konsekuensi keterlibatan para bawahan dalam proses pengambilan keputusan tersebut.

Tetapi dengan berbagai kelemahannya, pemimpin yang demokratik tetap dipandang sebagai pemimpin terbaik karena kelebihan-kelebihannya mengalahkan kekurangankekurangannya

Pertama ditinjau dari segi persepsinya tentang kehadiran atau keberadaannya dan peranannya selaku pemimpin dalam kehidupan organisasional. Pemimpin yang demokratik biasanya memandang peranannya selaku koordinator dan integrator dari berbagai unsur dan komponen organisasi sehingga bergerak sebagai suatu totalitas. Karena itu pendekatannya 
dalam menjalankan fungsi-fungsi kepemimpinannya adalah pendekatan yang holistik dan integralistik. Seorang pemimpin yang demokratik biasanya menyadari bahwa mau tidak mau organisasi harus disusun sedemikian rupa sehingga menggambarkan secara jelas aneka ragam tugas dan kegiatan yang berbagai sasaran organisasi. Akan tetapi dia mengetahui pula bahwa perbedaan tugas dan kegiatan, yang sering bersifat spesialistik itu, tidak boleh dibiarkan menimbulkan cara berpikir dan cara bertindak yang berkotak-kotak.

Seorang pemimpin yang demokratik menyadari benar-benar bahwa akan timbul kecendrungan di kalangan para pejabat pimpinan yang lebih rendah dan dikalangan para anggota organisasi untuk melihat peranan satuan kerja dimana mereka berada sebagai peranan yang paling penting, paling strategik dan paling menentukan keberhasilan organisasi mencapai berbagai sasaran organisasional. Sampai pada tingkat tertentu persepsi demikian akan dibiarkannya bertumbuh, akan tetapi tidak berkembang sedemikian rupa sehingga menimbulkan persasingan yang tidak sehat dalam organisasi. Persaingan yang tidak sehat tidak akan dibiarkannya berkembang karena ia mengetahui bahwa dengan persaingan yang tidak sehat dalam organisasi pada gilirannya akan menimbulkan pemborosan dari sumber daya dan dana yang terbatas, dan dapat merusak suasana kebersamaan yang bagaimanapun harus dipertahankan dan ditumbuhsuburkan dalam organisasi. Singkatnya, seorang pemimpin yang demokratik melihat bahwa dalam perbedaan yang merupakan kenyataan hidup, harus terjamin kebersamaan.

Ciri-ciri gaya kepemimpinan demokratis sebagai berikut:

a. sebagai hasil keputusan dibuat bersama

b. mau mendengarkan saran dan pendapat bawahan

c. menggunakan komunikasi dua arah

d. pemimpin bersedia melimpahkan sebahagian wewenang

e. pimpinan kritis objektif dalam memberikan pujian dan kritik

f. pengawasan dilakukan dengan wajar.

\subsection{Kerangka Konseptual}

PT Semen Tonasa Kabupaten Pangkajene Kepulauan merupakan organisasi yang bergerak dalam industri semen yang memiliki beberapa bagian dalam struktur organisasinya, salah satunya ialah bagian Biro Inventory.Biro Inventory PT Semen Tonasa Kabupaten Pangkajene Kepulauan adalah bagian yang bertanggungjawab penuh dalam mengelola persediaan pada PT Semen Tonasa Kabupaten Pangkajene Kepulauan. Biro Inventory sebagai sebuah bagian dari organisasi juga memiliki pemimpin yang biasa disebut kepala Biro Inventory. Sebagai pemimpin, Kepala Biro haruslah memiliki kepemimimpinan yang tepat agar seluruh elemen pada bagian Biro Inventory dapat berjalan dan terkoordinasikan dengan baik dan teratur.

Untuk lebih jelasnya dapat dibuat pada kerangka konseptual pada gambar berikut: 
Gambar 1

Kerangka Konseptual

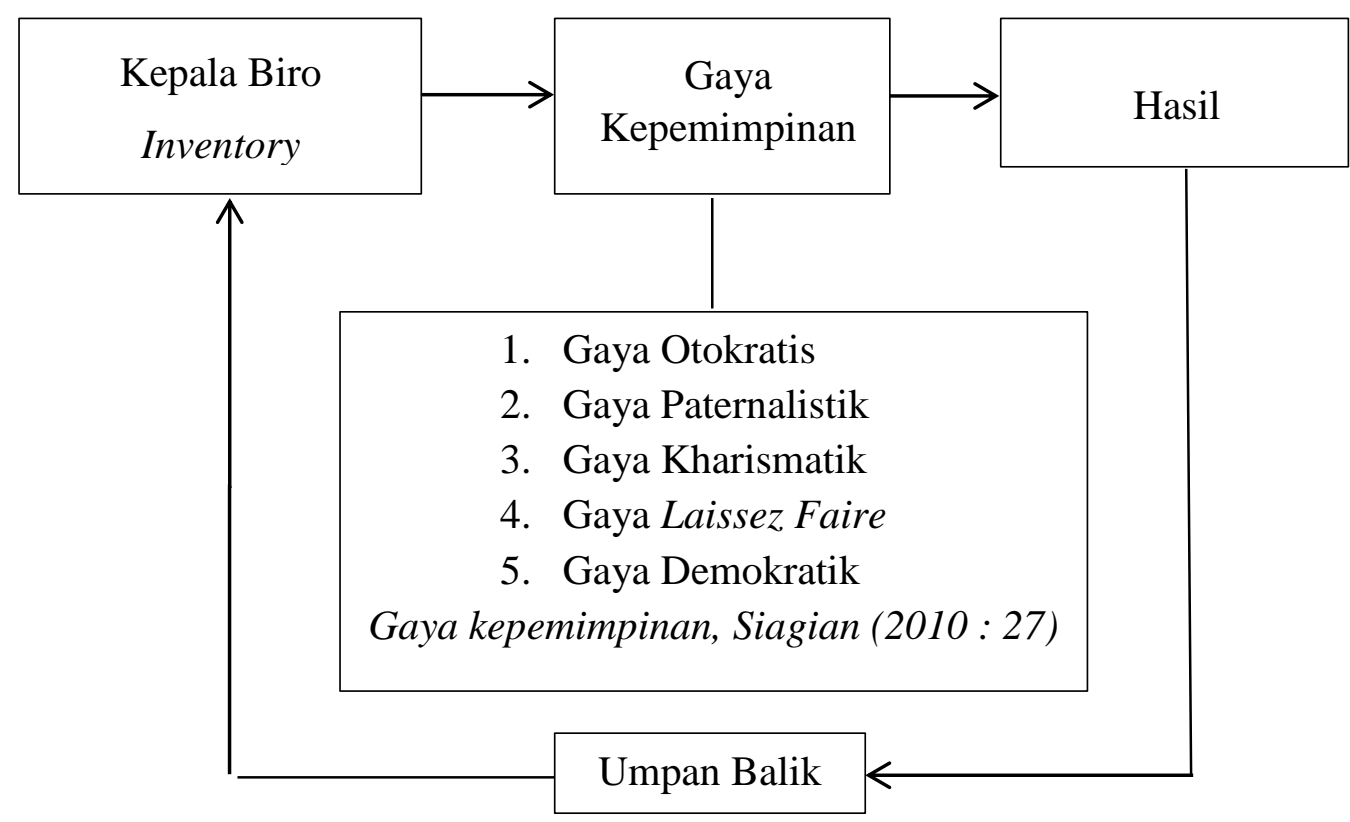

\section{METODE PENELITIAN}

\subsection{Tempat dan Waktu Penelitian}

Penelitian ini dilaksanakan di kantor Biro Inventory PT Semen Tonasa Kabupaten Pangkajene Kepulauan. Adapun waktu yang digunakan untuk melakukan penelitian ini selama 1 bulan, yaitu terhitung sejak bulan Agustus 2019.

\subsection{Populasi dan Sampel}

Populasi yaitu wilayah generalisasi yang terdiri dari objek dan subjek yang mempunyai jumlah dan karakteristik tertentu yang ditetapkan oleh peneliti untuk dianalisis dan kemudian ditarik kesimpulannya Sugiyono, (2016). Adapun populasi dalam penelitian ini adalah seluruh karyawan Biro Inventory PT Semen Tonasa Kabupaten Pangkajene Kepulauan, yaitu sebanyak 32 orang.

Sampel menurut Nawawi dalam Pasolong (2013), adalah sebagai bagian dari populasi yang menjadi sumber data yang sebenarnya dalam suatu penelitian. Teknik penarikan sampel yang digunakan adalah sampel jenuh yang digunakan untuk menentukan keseluruhan anggota yang dijadikan sebagai sampel. Dengan demikian, sampel yang digunakan dalam penelitian ini adalah seluruh karyawan Biro Inventory PT Semen Tonasa Kabupaten Pangkajene Kepulauan, yaitu sebanyak 32 orang dengan rincian sebagai berikut:

Sebagai Informan:

Manager

Sebagai Responden:

1 orang

Manager

Kepala Bagian/ Supervisor

3 orang

6 orang

Staf Unit Layanan dan Inventory

22 orang +

Jumlah

31 orang

\subsection{Teknik Pengumpulan Data}

Teknik pengumpulan data yang digunakan menggunakan kuesioner dan wawancara langsung. Kuesioner adalah suatu pengumpulan data melalui daftar pertanyaan yang diisi oleh responden itu sendiri. Pasolong (2005). Adapun wawancara secara langsung merupakan 
pembicaraan dua arah yang dilakukan oleh pewawancara (interviewer) terhadap responden atau informan, untuk menggali informasi yang relevan dengan tujuan penelitian. Pasolong (2013)

\subsection{Tipe Penelitian}

Tipe Penelitian yang digunakan adalah penelitian deskriptif yang menggambarkan Gaya Kepemimpinan Kepala Biro Inventory PT Semen Tonasa Kabupaten Pangkajene Kepulauan Periode 2019.

\subsection{Analisis Data}

Penelitian menggunakan teknik analisis data kuantitatif. Selanjutnya, untuk mengukur jawaban responden akan dianalisis dengan menggunakan tabel distribusi frekuensi.

Adapun mengenai kategori dan skor pada pada tabel akan menggunakan kategori dan skor skala likert Seperti dibawah ini:

Sangat sesuai diberi skor $\quad 5$

Sesuai diberi skor 4

Cukup sesuai diberi skor $\quad 3$

Tidak sesuai diberi skor $\quad 2$

Sangat tidak sesuai diberi skor 1

Bila jumlah responden ada 31 maka skala interval yang dihasilkan adalah sebagai berikut:

\section{Tabel 1}

Kategori Skor untuk Setiap Pernyataan

\begin{tabular}{cc}
\hline Interval Skor & Kategori \\
\hline $125-155$ & Sangat Sesuai (SS) \\
$94-124$ & Sesuai (S) \\
$63-93$ & Cukup Sesuai (CS) \\
$32-62$ & Tidak Sesuai (TS) \\
$0-31$ & Sangat Tidak Sesuai (STS) \\
\hline
\end{tabular}

\subsection{Definisi Operasional}

Gaya kepemimpinan adalah berbagai pola tingkah laku yang disukai oleh pemimpin dalam proses mengarahkan dan mempengaruhi pekerja.

Meskipun belum terdapat kesepakatan tentang gaya kepemimpinan yang secara luas dikenal dewasa ini, maka lima gaya kepemimpinan seperti berikut ini.

\section{Gaya Otokratik}

Adapun indikator gaya kepemimpinan otokratik yaitu:

a. Pimpinan menentukan semua keputusan mengenai kebijakan.

b. Setiap langkah-langkah kegiatan didikte oleh atasan setiap waktu, sehingga langkah-langkah yang akan datang selalu tidak pasti untuk tingkat yang luas.

c. Pimpinan cenderung lebih pribadi dalam pemberian penghargaan dan kritik terhadap setiap anggota kelompok.

d. Pimpinan kurang memperhatikan kebutuhan bawahan.

e. Pimpinan cenderung tidak mau menerima pendapat, saran, dan kritik dari bawahannya.

2. Gaya Paternalistik

Adapun indikator gaya kepemimpinan paternalistik yaitu:

a. Pimpinan menganggap bawahannya sebagai manusia yang tidak/belum dewasa, atau anak sendiri yang perlu dikembangkan.

b. Pimpinan bersikap terlalu melindungi

c. Pimpinan jarang memberikan kesempatan kepada bawahan untuk mengambil keputusan sendiri.

d. Pimpinan hampir tidak pernah memberikan kesempatan kepada bawahan untuk berinisiatif. 
e. Pimpinan hampir tidak pernah memberikan kesempatan pada pengikut atau bawahan unruk mengembangkan imajinasi dan daya kreatifitas sendiri.

\section{Gaya Kharismatik}

Adapun indikator gaya kepemimpinan kharismatik yaitu:

a. Pimpinan memiliki visi yang dinyatakan sebagai tujuan ideal.

b. Pimpinan menggunakan bentuk komunikasi yang kuat dan ekspresif saat menyampaikan visi.

c. Pimpinan bersedia mengambil resiko yang tinggi, mengeluarkan biaya besar, dan berkorban untuk mencapai visi tersebut.

d. Pimpinan mampu melakukan perhitungan realistis mengenai hambatan dari lingkungan dan kebutuhan sumberdaya untuk mengupayakan terjadinya perubahan.

e. Pimpinan menerima kemampuan orang lain dan bertanggungjawab atas kebutuhan dan perasaannya.

\section{Gaya Laissez Faire}

Adapun indikator gaya kepemimpinan laissez faire yaitu:

a. Kelompok mempunyai kebebasan sepenuhnya untuk mengambil keputusan dengan partisipasi minimal dari pimpinan.

b. Pimpinan memberikan kebebasan kepada bawahan untuk mengemukakan ide, saran, dan pendapat.

c. Kegiatan diberikan pimpinan dengan keterangan bahwa ia akan memberikan penjelasan jika diminta.

d. Pimpinan tidak pernah berpartisipasi secara penuh dalam penentuan tugas.

e. Kadang-kadang pimpinan memberikan komentar spontan terhadap kegiatan anggota atau pertanyaan dan tidak bermaksud menilai atau mengatur suatu kejadian.

\section{Gaya Demokratik}

Adapun indikator gaya kepemimpinan demokratik yaitu:

a. Semua kebijakan dirumuskan melalui musyawarah dan diputuskan oleh kelompok dengan dorongan dan bantuan dari pimpinan.

b. Pimpinan selalu menghargai ide, saran, dan pendapat dari bawahan.

c. Kegiatan ditetapkan secara bersama-sama untuk mencapai tujuan kelompok, apabila diperlukan saran teknis, pimpinan mengajukan beberapa alternatif untuk dipilih.

d. Pimpinan memberikan perhatian yang baik pada kenyamanan kerja bawahan.

e. Pimpinan bersikap objektif dan senantiasa berdasarkan fakta dalam memberikan penghargaan dan kritik. 


\section{HASIL DAN PEMBAHASAN}

\subsection{Gaya Kepemimpinan Kepala Biro Inventory PT Semen Tonasa Kabupaten Pangkajene} Kepulauan Periode 2019

Selanjutnya, untuk mengetahui gaya kepemimpinan kepala Biro Inventory pada PT Semen Tonasa Kabupaten Pangkajene Kepulauan Periode 2019, maka dapat dilihat dari penarapan gaya kepemimpinan seperti berikut ini:

Tabel 1

Kesimpulan Mengenai Penerapan Gaya Otokratik

\begin{tabular}{|c|c|c|c|c|c|c|c|}
\hline \multirow{3}{*}{ Indikator } & \multicolumn{5}{|c|}{ Tanggapan } & \multirow{3}{*}{$\mathbf{F}$} & \multirow{3}{*}{$\begin{array}{l}\text { Total } \\
\text { Skor }\end{array}$} \\
\hline & 5 & 4 & $\mathbf{3}$ & 2 & 1 & & \\
\hline & SS & $\mathbf{S}$ & CS & TS & STS & & \\
\hline $\mathrm{A}$ & 9 & 10 & 7 & 4 & 1 & 31 & 115 \\
\hline B & 7 & 10 & 9 & 5 & 0 & 31 & 112 \\
\hline $\mathrm{C}$ & 4 & 10 & 11 & 4 & 2 & 31 & 103 \\
\hline $\mathrm{D}$ & 7 & 10 & 9 & 4 & 1 & 31 & 111 \\
\hline $\mathrm{E}$ & 5 & 12 & 10 & 4 & 0 & 31 & 111 \\
\hline & & & & & & & 552 \\
\hline Skor Rata & kor & uml & ind & ato & & & 110,4 \\
\hline
\end{tabular}

Sumber: Hasil Olah Data Kuesioner, Agustus 2019

Tabel 1 diatas menunjukkan bahwa Kepala Biro Inventory PT Semen Tonasa Kabupaten Pangkajene Kepulauan periode 2019 masuk dalam kategori "sangat sering" dalam penerapan gaya otokratik. Hal tersebut dapat dilihat dari jumlah skor rata-rata yang diberikan responden yaitu sebanyak 110,4.

Selanjutnya untuk mengetahui gaya kepemimpinan PaternalistikKepala Biro Inventory PT Semen TonasaKabupaten Pangkajene Kepulauan periode 2019, maka dapat kita amati pada pada tabel berikut sesuai dengan kesimpulan keseluruhan tabel yang telah dibahas pada pembahasan indikator masing-masing indikator di atas.

\section{Tabel 2}

Kesimpulan Mengenai Penerapan Gaya Paternalistik

\begin{tabular}{|c|c|c|c|c|c|c|c|}
\hline \multirow{3}{*}{ Indikator } & \multicolumn{5}{|c|}{ Tanggapan } & \multirow{3}{*}{$\mathbf{F}$} & \multirow{3}{*}{$\begin{array}{l}\text { Total } \\
\text { Skor }\end{array}$} \\
\hline & 5 & 4 & $\mathbf{3}$ & 2 & 1 & & \\
\hline & SS & $\mathbf{S}$ & CS & TS & STS & & \\
\hline A & 3 & 5 & 10 & 10 & 3 & 31 & 88 \\
\hline B & 1 & 7 & 10 & 12 & 1 & 31 & 88 \\
\hline $\mathrm{C}$ & 9 & 7 & 10 & 4 & 1 & 31 & 112 \\
\hline D & 7 & 11 & 6 & 5 & 2 & 31 & 109 \\
\hline E & 7 & 11 & 6 & 6 & 1 & 31 & 110 \\
\hline & & & & & & & 507 \\
\hline Skor Rata-I & or $/$ & Imla & indil & tor) & & & 101,4 \\
\hline
\end{tabular}

Sumber: Hasil Olah Data Kuesioner, Agustus 2019

Tabel 2 di atas menunjukkan bahwa Kepala Biro Inventory PT Semen Tonasa Kabupaten Pangkajene Kepulauan periode 2019 masuk dalam kategori "sesuai" dalam penerapan gaya paternalistik. Hal tersebut dapat dilihat dari jumlah skor rata-rata yang diberikan responden yaitu 101,4 . 
Selanjutnya untuk mengetahui gaya kepemimpinan Kharismatik Kepala Biro Inventory PT Semen TonasaKabupaten Pangkajene Kepulauan periode 2019, maka dapat kita amati pada pada tabel berikut sesuai dengan kesimpulan keseluruhan tabel yang telah dibahas pada pembahasan indikator masing-masing indikator diatas.

Tabel 3

Kesimpulan Mengenai Penerapan Gaya Kharismatik

\begin{tabular}{|c|c|c|c|c|c|c|c|}
\hline \multirow{3}{*}{ Indikator } & \multicolumn{5}{|c|}{ Tanggapan } & \multirow{3}{*}{$\mathbf{F}$} & \multirow{3}{*}{$\begin{array}{l}\text { Total } \\
\text { Skor }\end{array}$} \\
\hline & 5 & 4 & 3 & 2 & 1 & & \\
\hline & SS & $\mathbf{S}$ & $\mathbf{C S}$ & TS & STS & & \\
\hline $\mathrm{A}$ & 14 & 17 & 0 & 0 & 0 & 31 & 138 \\
\hline $\mathrm{B}$ & 10 & 19 & 2 & 0 & 0 & 31 & 132 \\
\hline $\mathrm{C}$ & 0 & 7 & 13 & 11 & 0 & 31 & 89 \\
\hline $\mathrm{D}$ & 0 & 0 & 1 & 29 & 1 & 31 & 62 \\
\hline $\mathrm{E}$ & 0 & 4 & 14 & 13 & 0 & 31 & 84 \\
\hline & & & & & & & 505 \\
\hline Skor Rata & kor / & umla & indil & tor) & & & 101 \\
\hline
\end{tabular}

Sumber: Hasil Olah Data Kuesioner, Agustus 2019

Tabel 3 di atas menunjukkan bahwa Kepala Biro Inventory PT Semen Tonasa Kabupaten Pangkajene Kepulauan periode 2019 masuk dalam kategori "sesuai" dalam penerapan gaya kharismatik. Hal tersebut dapat dilihat dari jumlah skor rata-rata yang diberikan responden yaitu sebanyak 101.

Selanjutnya untuk mengetahui gaya kepemimpinan Laissez Faire Kepala Biro Inventory PT Semen Tonasa Kabupaten Pangkajene Kepulauan periode 2019, maka dapat kita amati pada pada tabel berikut sesuai dengan kesimpulan keseluruhan tabel yang telah dibahas pada pembahasan indikator masing-masing indikator diatas.

\section{Tabel 4}

Kesimpulan Mengenai Penerapan Gaya Laissez Faire

\begin{tabular}{|c|c|c|c|c|c|c|c|}
\hline \multirow{3}{*}{ Indikator } & \multicolumn{5}{|c|}{ Tanggapan } & \multirow{3}{*}{$\mathbf{F}$} & \multirow{3}{*}{$\begin{array}{l}\text { Total } \\
\text { Skor }\end{array}$} \\
\hline & 5 & 4 & $\mathbf{3}$ & 2 & 1 & & \\
\hline & SS & $\mathbf{S}$ & CS & TS & STS & & \\
\hline A & 0 & 3 & 3 & 10 & 15 & 31 & 56 \\
\hline B & 0 & 1 & 1 & 17 & 12 & 31 & 53 \\
\hline $\mathrm{C}$ & 10 & 8 & 9 & 4 & 0 & 31 & 117 \\
\hline $\mathrm{D}$ & 0 & 0 & 0 & 17 & 14 & 31 & 48 \\
\hline E & 0 & 1 & 3 & 14 & 13 & 31 & 54 \\
\hline & & & & & & & 328 \\
\hline Skor Rata & kor & $\mathrm{Iml}$ & indil & tor) & & & 65,6 \\
\hline
\end{tabular}

Sumber: Hasil Olah Data Kuesioner, Agustus 2019

Tabel 4 di atas menunjukkan bahwa Kepala Biro Inventory PT Semen Tonasa Kabupaten Pangkajene Kepulauan periode 2019 masuk dalam kategori "cukup sesuai" dalam penerapan gaya laissez faire. Hal tersebut dapat dilihat dari jumlah skor rata-rata yang diberikan responden yaitu sebanyak 65,6. 
Selanjutnya untuk mengetahui gaya kepemimpinan Demokratik Kepala Biro Inventory PT Semen TonasaKabupaten Pangkajene Kepulauan periode 2019, maka dapat kita amati pada pada tabel berikut sesuai dengan kesimpulan keseluruhan tabel yang telah dibahas pada pembahasan indikator masing-masing indikator diatas.

\section{Tabel 5}

Kesimpulan Mengenai Penerapan Gaya Demokratik

\begin{tabular}{|c|c|c|c|c|c|c|c|}
\hline \multirow{3}{*}{ Indikator } & \multicolumn{5}{|c|}{ Tanggapan } & \multirow{3}{*}{$\mathbf{F}$} & \multirow{3}{*}{$\begin{array}{l}\text { Total } \\
\text { Skor }\end{array}$} \\
\hline & 5 & 4 & 3 & 2 & 1 & & \\
\hline & SS & $\mathbf{S}$ & CS & TS & STS & & \\
\hline A & 0 & 2 & 0 & 22 & 7 & 31 & 59 \\
\hline B & 0 & 2 & 0 & 13 & 16 & 31 & 50 \\
\hline $\mathrm{C}$ & 0 & 1 & 4 & 15 & 11 & 31 & 57 \\
\hline $\mathrm{D}$ & 2 & 3 & 0 & 5 & 21 & 31 & 53 \\
\hline $\mathrm{E}$ & 0 & 2 & 18 & 11 & 0 & 31 & 84 \\
\hline Skor Ra & ror / & llat & dika & & & & $\begin{array}{l}303 \\
60,6 \\
\end{array}$ \\
\hline
\end{tabular}

Sumber: Hasil Olah Data Kuesioner, Agustus 2019

Tabel 5 di atas menunjukkan bahwa Kepala Biro Inventory PT Semen Tonasa Kabupaten Pangkajene Kepulauan periode 2019 masuk dalam kategori "tidak sesuai" dalam penerapan gaya demokratik. Hal tersebut dapat dilihat dari jumlah skor rata-rata yang diberikan responden yaitu sebanyak 60,6.

Selanjutnya untuk mengetahui gaya kepemimpinan yang lebih dominan diterapkan oleh Kepala Biro Inventory PT Semen Tonasa Kabupaten Pangkajene Kepulauan periode 2019, maka dapat kita amati pada pada tabel berikut sesuai dengan kesimpulan keseluruhan tabel yang telah dibahas pada pembahasan indikator masing-masing gaya kepemimpinan di atas.

\section{Tabel 6}

Kesimpulan keseluruhan tabel mengenai gaya kepemimpinan Kepala Biro Inventory PT Semen TonasaKabupaten Pangkajene Kepulauan periode 2019

\begin{tabular}{ccccccccc}
\hline \multirow{2}{*}{$\begin{array}{c}\text { Gaya } \\
\text { Kepemimpinan }\end{array}$} & $\mathbf{5}$ & $\mathbf{4}$ & $\mathbf{3}$ & $\mathbf{2}$ & $\mathbf{1}$ & & Total & \\
\cline { 2 - 6 } & $\mathbf{S S}$ & $\mathbf{S}$ & $\mathbf{C S}$ & $\mathbf{T S}$ & STS & Frekuensi & Skor & $\begin{array}{c}\text { Skor } \\
\text { Rata- rata }\end{array}$ \\
\hline Otokratik & 32 & 52 & 46 & 21 & 4 & 155 & 552 & 110,4 \\
Paternalistik & 27 & 41 & 42 & 37 & 8 & 155 & 507 & 101,4 \\
Kharismatik & 24 & 47 & 30 & 53 & 1 & 155 & 505 & 101 \\
Laissez Faire & 10 & 13 & 16 & 62 & 54 & 155 & 328 & 65,6 \\
Demokratik & 2 & 10 & 22 & 66 & 55 & 155 & 303 & 60,6 \\
\hline
\end{tabular}

Sumber: Hasil Olah Data Kuesioner, Agustus 2019

Tabel 6 di atas menunjukkan bahwa dari lima gaya kepemimpinan yang telah dibahas, responden (karyawan Biro Inventory PT Semen Tonasa Kabupaten Pangkajene Kepulauan Periode 2019) menyatakan bahwa kepala Biro Inventory PT Semen Tonasa Kabupaten Pangkajene Kepulauan Periode 2019 lebih dominan menggunakan gaya otokratik, dapat dilihat dari total skor yang dicapai sebanyak 552 atau skor rata-rata 110,4. Gaya Paternalistik berada pada urutan kedua, dapat dilihat dari total skor sebanyak 507 atau skor rata-rata 101,4. Gaya Kharismatik berada pada urutan ketiga, dapat dilihat dari total skor sebanyak 505 atau skor rata-rata 101. Gaya laissezfaire berada pada urutan keempat, dapat dilihat dari total skor sebanyak 328 atau skor rata-rata 65,6. 
Selanjutnya Gaya demokratik berada pada urutan terakhir, dapat dilihat dari total skor sebanyak 303 atau skor rata-rata 60,6.

\section{KESIMPULAN DAN SARAN \\ 5.1 Kesimpulan}

Berdasarkan pada pembahasan dan hasil penelitian tentang gaya kepemimpinan Kepala Biro Inventory PT Semen Tonasa Kabupaten Pangkajene Kepulauan periode 2019, maka dapat ditarik kesimpulan bahwa dari kelima gaya kepemimpinan yang dibahas, gaya kepemimpinan yang lebih dominan diterapkan atau digunakan oleh Kepala Biro Inventory PT Semen Tonasa Kabupaten Pangkajene Kepulauan periode 2019 adalah gaya kepemimpinan "otokratik". Hal ini terlihat pada bab hasil dan pembahasan yang menyatakan pimpinan hampir selalu menentukan kebijakan, mendikte setiap langkah-langkah bawahan, kurang memperhatikan kebutuhan bawahan, dan kurang dalam hal menerima pendapat maupun kritik dari bawahannya. Gaya paternalistik berada pada urutan kedua, diikuti gaya kharismatik yang berada pada urutan ketiga, selanjutnya gaya laissez faire berada pada urutan keempat, dan Gaya demokratik berada pada urutan terakhir yang diterapkan oleh Kepala Biro Inventory PT Semen Tonasa Kabupaten Pangkajene Kepulauan periode 2019.

\subsection{Saran}

Adapun saran yang dapat penulis sampaikan adalah sebagai berikut:

1. Pimpinan sebaiknya meningkatkan hubungan baik dengan seluruh karyawan agar terjalin hubungan yang harmonis dan kondisi kerja yang lebih baik.

2. Pimpinan sebaiknya lebih menunjukkan perannya dalam menghadapi situasi dan kondisi serta perilaku para bawahannya seperti ketika terjadi konflik internal pada karyawan, agar supaya masalah yang terjadi tidak berlarut-larut dan tidak mempengaruhi produktifitas kerja.

3. Pimpinan sebaiknya lebih memeberikan kebebasan kepada karyawan dalam menyalurkan aspirasi seperti ketika karayawan menyampaikan pendapat, memberikan ide maupun saran. Agar karyawan lebih merasa dihargai dan dapat menjalankan tugasnya dengan lebih baik.

\section{UCAPAN TERIMA KASIH}

Penulis mengucapkan banyak terima kasih kepada pimpinan dan karyawan PT Semen Tonasa di Kabupaten Pangkajene dan Kepualauan, para responden dan semua pihak yang telah membantu dalam kegiatan penelitian.

\section{DAFTAR PUSTAKA}

Kartono, K. (2016). Pemimpin dan kepemimpinan. Depok: Raja Grafindo Persada.

Nawawi, H. (2016). Kepemimpinan mengefektifkan organisai. Yogyakarta: Gadjah Mada University Press.

Northouse, PG. (2013). Kepemimpinan : Teori dan praktek, (Edisi Keenam). Alih Bahasa: Dr. Ati Cahayani. Indonesia: PT Indeks.

Nur, P. (2017). Kepemimpinan. Yogyakarta: Relasi Inti Media Group.

Pasolong, H. (2005). Metode penelitian administrasi untuk organisasi profit dan non-profit.

Makassar: Lembaga Penerbitan Universitas Hasanuddin. . (2017). Metode penelitian administrasi publik. Bandung: Alfabeta. (2019). Teori administrasi publik. Bandung: Alfabeta (2019). Kepemimpinan birokrasi. Bandung: Alfabeta. 
Rivai, B \& Amar. (2013). Pemimpin dan kepemimpinan dalam organisasi. Jakarta: Rajawali Pers. Robbins, S.P. (2010). Perilaku organisasi (edisi kesepuluh). Alih Bahasa: Benyamin Molan. Indonesia: PT. Indeks.

Rukmana, N. (2007). Etika kepemimpinan: perspektif agama dan moral. Bandung: Alfabeta. Siagian, S. (2010). Teori dan praktek kepemimpinan (edisi keenam). Jakarta: Aneka Cipta. Sugiyono. (2016). Metode penelitian administrasi dilengkapi dengan metode r\&d. Bandung: Alfabeta.

Sugiyono. (2018). Metode penelitian kuantitatif, kualitatif, dan r\&d. Bandung. Alfabeta. Thoha, M. (2014). Perilaku organisasi: konsep dasar dan aplikasinya. Jakarta: Rajawali Pers.

Wibowo. (2016). Kepemimpinan pemahaman dasar, pandangan konvensional, gagasan kontemporeer. Jakarta: Rajawali Pers 